\title{
有限要素マトリックスの定式過程に関する一考察
}

\section{A STUDY ON FORMULATIONS OF FINITE ELEMENT MATRICES}

\author{
吉田裕* \\ By Yutaka Yoshida
}

\section{1. 序論}

平板曲げの問題は, それ自体が構造系の中で重要な位 置を占めていると同時に, 殸構造の解析への基礎となる 問題であるために, 構造力学における中心的研究課題の 一つとして位置づけられている。

したがって, 有限要素法が具体化された初期の段階か ら,この解法を平板曲げの解析に適用することが行なわ れ, 数多くの成果があげられてきた。しかし, 平板曲げ の問題においては, 面外の変位を対象とするといら意味 での三次元の変位曲面を扱うために種々の困難が内在す る。そのために, 有限要素マトリックスの定式過程に関 して各方向から研究がなされ, 有限要素法の基礎理論的 発展は平板曲げの問題を対象としてなされてきたといっ ても過言ではない。

その中で, Reissner の変分原理に基づいて L.R. Herrmann によって誘導された有限要素マトリックス ${ }^{12)}$ は, 変位と応力を混合した要素であるが, 定式過程の卓抜さ と, 要素の自由度にくらべて解析精度が高いことのため に高く評価されている。

有限要素マトリックスの誘導過程の相違は, 有限要素 法を Ritz 法の一般形としてとらえ, 変分原理を通して 明確に説明することができるが，その際の重要な議論 は, 変位や応力の要素間における連続性の問題である。

上記 Herrmann の要素 ${ }^{1}$ の特徵は, 変位分布の仮定に 基づいた平板曲げの有限要素マトリックスの定式過程に おいてもっとも問題となってきた, 要素周辺における要 素間の法線方向のたわみの勾配の連続の要求を, これに 対応する曲げモーメントの連続を保証することによって 置き換えた点にあるということができる。

本報告の目的の第 1 は, 変分原理に基づいた理論的差 異にもかかわらず，上記 Herrmann の要素とまったく

\footnotetext{
* 正会員 工博 東京大学助教授 生産技術研究所
}

同一の要素が一般の応力仮定や变位仮定からも誘導しう ることを示すことにある。

このような事実から, 一般の Rayleigh-Ritz 法の場合 のように, 仮定された変位や応力の分布型が構造全体に おいて高次の領域まで連続で，また仮定された分布型そ れ自体において無限の自由度をとりらるよらに設定する 場合, すなわち, 仮定した変位または応力分布型に真の 分布型を内包する場合と, 有限要素解析において一般に とられているように, 要素内で仮定された変位や応力分 布型は有限の自由度に固定し, 対象を構成する要素の数 を増加することによって対象全体の自由度を高め, 実際 の系に近づけようとする場合との基本的な相違が明確に される。すなわち, 有限要素法の特性として明記しなけ ればならないのは, 有限要素法においては要素内の領域 において仮定された変位または応力分布型では対応でき ない高次の分布型を必要 とする作用荷重分布に対して は, 対象全体としての系の自由度がいかに高められて も, 要素内の変位分布型または応力分布型自体が真の分 布型となることができず, あくまでも, 要素周辺におけ る要素間の高次の不連続量によって表わされる等価な平 衡関係が真の分布型を評価しらるように近づくことによ って収束が保証されるといらことである。

一般の有限要素解析における, 要素間の変位や応力の 連続性に関する議論を上記の見地から再考し，いわゆる 節点変位や節点力の物理的意義を明確にすることにより 有限要素解析の新たな可能性を考えることができる。

まず, 有限要素法による平板曲げの解析の現況を概括 し, そこに内在する問題点を明確にし, Herrmann の要 素の位置づけを行なってみたい。

その後に，この Herrmann の平板曲げ要素”を著者な りに整理し直し, 定式過程をより具体化し, 内容を明確 にすると同時に, この Herrmann の要素とまったく同 一の要素が一般の応力仮定や変位仮定からも誘導しらる ことを示してみたいと思ら。 
また，そのような事実に基づいて有限要素マトリック スの定式過程に関する二, 三の考察を行なってみたい。

\section{2. 有限要素法による平板曲げの解析}

有効な平板曲げの有限要素を開発しようとするとき問 題となるのは, 要素の周辺に颃いて適合条件を満足する ような要素の変形の型を設定することである。もし，変 位形を 2 次元の完全な形の多項式で表現することができ るならば, 座標変換にも矛盾を生ずることがなく, また その領域内のいかなる直線上の変位形も仮定した変位形 と同じ次数の多項式で表現され，ある特定の変形型を強 調するという矛盾が生じないという意味で, 変位形を完 全な形の多項式で表わすことが望ましい。しかし，完全 な形の多項式の項数と実用上の要求から要素に設定され る一般化変位の数, すなわち要素の自由度の数とが一致 する場合はごくまれで, 変位形を多項式で近似しようと すれば，多くの場合不完全な多項式を用いざるをえなく なる。

実用的視点からは三角形要素の 3 つの頂点に設けたそ れぞれの節点において，たわみ(w) と直交する 2 方向の たわみの勾配 ( $\partial w / \partial x, \partial w / \partial y)$ を節点変位として設定 した 9 自由度の要素が有効である。したがって，このよ うな 9 自由度の三角形要素を種々の不完全な多項式で与 えた変位関数をもとにして誘導することが行なわれた。 その結果, 12 の自由度を有する矩形要素 ${ }^{3}$ が比較的よい 結果を与えるのに対して, このような三角形要素は, 設 定された変位関数の内容によって著しい違いが生ずるこ と, また要素の大きさを小さくしても, かならずしも正 解に収束するとは限らないものも存在することがわかっ だ)。

その原因は, 仮定した変位形が要素の縁に沿っての適 合条件を満足しないためであると説明される。したがっ て, 辺を共有する隣接する 2 つの要素間で境界辺の法線 方向のたわみの勾配の連続性が保証されるような変位関 数の与え方について種々の工夫がなされた。たとえば, 境界辺上で法線方向のたわみの勾配が直線的に変化する ものと仮定すれば，その境界辺の両端で与えられる法線 方向の勾配に関する 2 つの条件によって辺上のすべての 点の法線方向の勾配が一義的に決定されるから，その境 界辺を共有する 2 つ要素に関して, その辺の法線方向 のたわみの勾配の連続性が確保される。しかし，このよ らな場合には，節点におけるねじれ ( $\left.\partial^{2} w / \partial x \partial y\right)$ の值 は一般に一義的に決めることができなくなる5)。

また, 法線方向の勾配の連続性を保証するという立場 から, 辺上にも節点を設けた自由度の高い要素を用いる ことが考えられる。このような要素として, たとえば,
三角形要素の各頂点で $3 つ(w, \partial w / \partial x, \partial w / \partial y)$, 各 辺の中央で $3 \supset\left(w, \partial w / \partial n, \partial^{2} w / \partial n \partial s\right)$ ずつの変位成 分を有する節点変位を設定した 18 自由度の要素が考え られている6)。しかし，この場合にも要素の隅の節点に おいて, たわみの 2 次微係数の意味が不明確になるとい う特異性は残されることになる。

もら一つの方向として, たわみの 2 次微係数を含めた 節点変位を設定することが考えられる。このような要素 として,たとえば変位関数を完全な 5 次の多項式で与 え, 三角形要素の各頂点に $6 \supset(w, \partial w / \partial x, \partial w / \partial y$, $\left.\partial^{2} w / \partial x^{2}, \partial^{2} w / \partial x \partial y, \partial^{2} w / \partial y^{2}\right)$ の変位成分を持つ節 点変位を設定し, 各辺の中央に辺の法線方向の勾配 $(\partial w / \partial n)$ を成分とする節点変位を設定した 21 自由度 の要素が誘導されている7)。この場合には, 節点におい て 3 つのたわみの 2 次微係数のすべてが連続することに なるが，境界をはさんで板厚が不連続なものを対象とす るときには, 実際には曲げモーメントが連続でなければ ならないので, 理論的に 3 つの 2 次微係数のすべてが連 続することはなく，したがって，このような自由度の高 い要素にも問題点が残ることになる。

要素の変位関数は, 本来節点変位 $u_{i}$ の補間関数 $\phi_{i}$ $(x, y)$ の線形結合として

$$
w(x, y)=\Sigma u_{i} \phi_{i}(x, y)
$$

のように与えられるものである。したがって, 変位関数 を多項式で与えた場合には, 多項式の係数べクトル $\boldsymbol{q}$ を節点変位ベクトル $\boldsymbol{u}$ の関数として表現し, 式 (1) の形の変位関数に変換する必要がある。その意味で, 個 々の要素に固有な座標系による変位関数の表現が効果的 になり, また, 境界辺上の法線方向のたわみの勾配の適 合条件を満足する変位関数を求めるといら意味でも, 面 積座標などによる補間関数の研究が進められた ${ }^{8) 910) 。 ~}$

有限要素の暁性マトリックスに基づいた解析は, エネ ルギーの相補関係から必然的に考えられることであり， 早くからその一般理論が展開され ${ }^{1112)}$, 板の曲げの問題

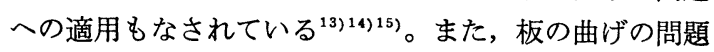
と平面応力問題との間の力学的, 幾何学的な相似性に基 ついた研究も行なわれている(16)17)18)。

しかし, 応力系に基づいた解析においては, 幾何学的 視点が明確に表われないために, 変位系に基づいた解析 ほど広く一般的になっていない。

したがって, 応力仮定から出発する場合においても, 要素内で応力分布を仮定し, 要素周辺の変位を節点変位 の関数として与えて, 要素の剛性マトリックスを誘導し ようとする立場が効果的である。この方法は, 応力分布 を代数方程式で仮定した平面応力問題に対して最初に与 えられた ${ }^{19)} 。 こ の$ 方法の平板曲げの問題への適用は, 最 初に矩形要素に対してなされ20), 次に矩形および直角三 
角形要素に対して具体化された ${ }^{21)}$ 。また，この方法によ る任意の多角形要素の誘導も行なわれている ${ }^{22) 。 ~}$

これに対して, 要素内で変位分布を仮定し, 要素の境 界に沿って, 平衡条件を満たす力を仮定して誘導するこ とも行なわれている ${ }^{23)}$ 。

このような状況の中で, Reissnerの変分原理に基づい て誘導された, 変位と応力を混合した有限要素マトリッ クス ${ }^{12)}$ は, 定式過程の卓抜さと, 要素の 自由度にくら べて解析精度が高いことのために高く評価されている。

有限要素 マトリックスの定式化の際に問題となるの は, 個々の要素内の変位分布または応力分布が, その要 素に属する節点において代表される有限個の節点変位ま たは節点力によって支配される, 要素内で連続な関数と して仮定されるとき, 要素周辺における要素間の変位ま たは応力の連続性をいかにして保証するかといらことで ある。連続体の変位や応力分布は, 作用荷重の任意性に 対応して本来無限の自由度を有するものであり, これを 有限の自由度の系として理想化する限りにおいては, 変 位と応力の両者の要素間の連続性を，作用荷重条件など にかかわりなく常に，完全に満たすということは不可能 である。

したがって, 要素周辺における要素間の変位と応力の 連続の要求のうち，いずれか一方を緩和することにな り, 変位分布または応力分布のとり方および要素周辺の 連続性に対する要求の違いの組み合わせによって, 種々 の異なった有限要素マトリックスが誘導されることにな る。

このような有限要素 マトリックスの誘導過程の相違 は，有限要素法を Ritz 法の一般形としてとらえる ことにより，変分原理を通して明確に説明されてい る 2124) 25) 26) 27)。

ここで, 上記 Herrmann の平板曲げ要素 ${ }^{1}$ を著者なり に整理し直し，定式過程をより具体化し，内容を明確に する。

\section{Herrmann の平板曲げ要素}

平板曲げの問題に対 して, Reissner のエネルギー関 数 $\Pi_{R}$ は次のように与えられる。すなわち,

$$
\begin{aligned}
\Pi_{R}= & \int_{A}\left[-M^{\alpha \beta} w,_{\alpha \beta}-B\left(M^{\alpha \beta}\right)-\bar{p} w\right] d A \\
& +\int_{S_{1}}\left(\bar{M}_{n} w,_{n}+\bar{M}_{n s} w,_{s}-\bar{Q}_{n} w\right) d S \\
& +\int_{S_{2}}\left[M_{n}\left(w,_{n}-\bar{w},{ }_{n}\right)+M_{n s}\left(w,,_{s}-\bar{w},{ }_{s}\right)\right. \\
& \left.-Q_{n}(w-\bar{w})\right] d S \ldots \ldots \ldots \ldots \ldots \ldots \ldots . . .
\end{aligned}
$$

ここに,

$$
M^{\alpha \beta} w,_{\alpha \beta}=M_{x} w,_{x x}+M_{y} w,_{y y}+2 M_{x y} w, x y
$$

であり， $B\left(M^{\alpha \beta}\right)$ は相補エネルギー密度で

$$
\begin{aligned}
& B\left(M^{\alpha \beta}\right)=\frac{6}{E h^{3}}\left[M_{x}{ }^{2}+M_{y}{ }^{2}-2 \nu M_{x} M_{y}\right. \\
& \left.+2(1+\nu) M_{x y}{ }^{2}\right] \text {. }
\end{aligned}
$$

である。また, $w,_{n}=\partial w / \partial n, \quad w,_{s}=\partial w / \partial s, \cdots \cdots$ であ り， $S_{1}$ は境界周辺 $S$ のらち力学的境界条件が与えられ ている部分, $S_{2}$ は幾何学的境界条件が 与えられている 部分である。また, $\bar{M}_{n}, \bar{M}_{n s}, \bar{Q}_{n}$ は与えられた境界力 であり, $\bar{w},{ }_{n}, \bar{w},{ }_{s}, \bar{w}$ は与えられた幾何学的境界条件で ある。

式（2）に与えた関数を有限要素解析に適用するにあ たって, 変位 $w$ と要素周辺の法線方向の勾配 $w,{ }_{n}$ を各 要素間において連続させることを考えるならば，式 (2) の対象全体の面積にわたる積分は個々の要素の積分の総 和と等しくなり, 式 (2) を直接有限要素解析に適用す ることが可能である。

しかし，要素間において，変位 $M_{n}$ を連続させることを考えるならば，法線方向の勾配 $w,{ }_{n}$ の不連続を許すことになり, 各要素の積分の総和と しての関数 $\Pi_{R}$ は次のように書くことができる。すなわ ち,

$$
\begin{aligned}
\Pi_{R}= & \sum \int_{A_{m}}\left[-M^{\alpha \beta} w,_{\alpha \beta}-B\left(M^{\alpha \beta}\right)-\bar{p} w\right] d A \\
& +\oint_{S_{m}} M_{n} w,_{n} d S+\int_{S_{1 m}}\left[\left(\bar{M}_{n}-M_{n}\right) w_{,_{n}}\right. \\
& \left.+\bar{M}_{n s} w,_{s}-\bar{Q}_{n} w\right] d S \\
& +\int_{S_{s m}}\left[-M_{n} \bar{w},_{n}+M_{n s}\left(w,_{s}-\bar{w},{ }_{s}\right)\right. \\
& \left.\left.-Q_{n}(w-\bar{w})\right] d S\right\} \ldots \ldots \ldots \ldots \ldots \ldots \ldots . . .(5)
\end{aligned}
$$

ここに, $S_{1 m}$ は要素 $m$ の周辺のうち $S_{1}$ に含まれる部 分, また, $S_{2 m}$ は $S_{2}$ に含まれる部分であり, $S_{m}$ は要 素 $m$ の全周である。

式（5）における $M^{\alpha \beta} w_{\alpha \beta}$ の項は部分積分によっ て，次のように変換することができる。すなわち，

$$
\begin{aligned}
& \int_{A_{m}} M^{\alpha \beta} w,_{\alpha \beta} d A \\
& =\int_{A_{m}}\left(M_{x} w,,_{x x}+M_{y} w,_{y y}+2 M_{x y} w,_{x y}\right) d A \\
& =\oint_{S_{m}}\left(M_{n} w,_{n}+M_{n s} w,{ }_{s}\right) d S \\
& -\int_{A_{m}} M,{ }_{\beta}{ }^{\alpha \beta} w,{ }_{\alpha} d A
\end{aligned}
$$

したがって, 式 (5) は次のように書き改められる。す なわち,

$$
\begin{aligned}
\Pi_{R}= & \sum_{m}\left\{\int_{A_{m}}\left[M,_{\beta}{ }^{\alpha \beta} w,_{\alpha}-B\left(M^{\alpha \beta}\right)-\bar{p} w\right] d A\right. \\
& -\oint_{S_{m}} M_{n s} w,_{s} d S
\end{aligned}
$$




$$
\begin{aligned}
& +\int_{S_{1 m}}\left[\left(\bar{M}_{n}-M_{n}\right) w,_{n}-\bar{V}_{n} w\right] d S \\
& \left.-\int_{S_{2 m}}\left[M_{n} \bar{w},_{n}+V_{n}(w-\bar{w})\right] d S\right\}
\end{aligned}
$$

ここに,

$$
V_{n}=Q_{n}+M_{n s}, s
$$

である。

いま，与えられた境界条件としての曲げモーメント

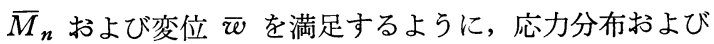
変位分布を仮定するものとすれば，式（7）は

$$
\begin{aligned}
\Pi_{R}= & \sum_{m}\left\{\int_{A_{m}}\left[M,_{\beta}{ }^{\alpha \beta} w,_{\alpha}-B\left(M^{\alpha \beta}\right)-\bar{p} w\right] d A\right. \\
& -\oint_{S_{m}} M_{n s} w,_{s} d S-\int_{S_{1 m}} \bar{V}_{n} w d S \\
& \left.-\int_{S_{2 m}} M_{n} \bar{w},{ }_{n} d S\right\} \cdots \cdots \cdots \cdots \cdots \cdots \cdots \cdots(8)
\end{aligned}
$$

のようになる。

Herrmann は, 要素間で変位 $w$ と曲げモーメント $M_{n}$ が連続するという条件を満たすもっとも簡単な変位 および応力分布として, 要素内で変位が $x, y$ の線形関 数であること执よび要素内でモーメント $M_{x}, M_{y}, M_{x y}$ が一定であると仮定して, 式 (8) により有限要素マト リックスの定式化を行なった。変位が要素内で線形であ れば変位分布を三角形要素の 3 つの頂点に設けた節点の 変位 $w_{i}(i=1,2,3)$ の関数として表現することができ, 要素間の変位の連続性が保証される。また, 要素内で一 定と仮定した $M_{x}, M_{y}, M_{x y}$ を三角形要素の各辺上の 曲げモーメント $M_{n i}(i=1,2,3)$ の関数として表現する ことにより, 要素間の曲げモーメント $M_{n}$ の連続性が保 証される。

ここで, 式（8）に基づいた有限要素マトリックスの 定式化を行なう。いま, 薄い板の曲げの弾性理論に基づ けば,曲率とモーメントの関係は次のように表わされる。

$$
\left\{\begin{array}{c}
w, x x \\
w, y y \\
2 w_{x y}
\end{array}\right\}=-\frac{12}{E h^{3}}\left[\begin{array}{rrc}
1 & -\nu & 0 \\
-\nu & 1 & 0 \\
0 & 0 & 2(1+\nu)
\end{array}\right]\left\{\begin{array}{l}
M_{x} \\
M_{y} \\
M_{x y}
\end{array}\right\}
$$

式 (9)を

$$
\boldsymbol{\epsilon}=-\boldsymbol{N} \boldsymbol{\sigma}
$$

のよらに書く。また, 要素の辺上における曲げモーメン ト $M_{n i}(i=1,2,3)$ は, 要素内で一定と仮定したモーメ ント $\boldsymbol{\sigma}$ の関数として

$$
\left\{\begin{array}{l}
M_{n 1} \\
M_{n 2} \\
M_{n 3}
\end{array}\right\}=\left[\begin{array}{llll}
c_{1}{ }^{2} & s_{1}{ }^{2} & 2 & s_{1} c_{1} \\
c_{2}{ }^{2} & s_{2}{ }^{2} & 2 & s_{2} c_{2} \\
{c_{3}}^{2} & s_{3}{ }^{2} & 2 & s_{3} c_{3}
\end{array}\right]\left\{\begin{array}{l}
M_{x} \\
M_{y} \\
M_{x y}
\end{array}\right\}
$$

のように表わされる (Fig. 1)。ここに，

$$
c_{i}=\cos \alpha_{i}, \quad s_{i}=\sin \alpha_{i}, \quad i=1,2,3
$$

であり， $\alpha_{i}$ は各辺の法線の $x$ 軸よりの角度である (Fig.

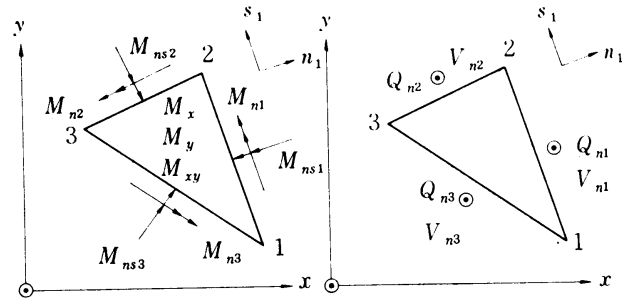

- Fig. 1 Moment and Shear Notation

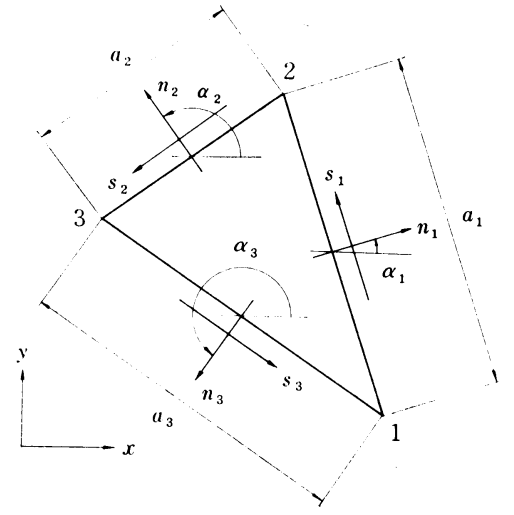

Fig. 2 Angle Notation

2)。式 (10)を

$$
\boldsymbol{\sigma}_{n}=\boldsymbol{E} \boldsymbol{\sigma}
$$

と書く。同様に, 要素の辺上におけるねじりモーメント $M_{n s i}(i=1,2,3)$ は, $\boldsymbol{\sigma}$ の関数として次のように与えら れる。

$$
\left\{\begin{array}{l}
M_{n s 1} \\
M_{n s 2} \\
M_{n s 3}
\end{array}\right\}=\left[\begin{array}{lll}
-s_{1} c_{1} & s_{1} c_{1} & c_{1}{ }^{2}-s_{1}{ }^{2} \\
-s_{2} c_{2} & s_{2} c_{2} & c_{2}{ }^{2}-s_{2}{ }^{2} \\
-s_{3} c_{3} & s_{3} c_{3} & c_{3}{ }^{2}-s_{3}{ }^{2}
\end{array}\right]\left\{\begin{array}{l}
M_{x} \\
M_{y} \\
M_{x y}
\end{array}\right\}
$$

式（11）を

$$
\boldsymbol{\sigma}_{n s}=\boldsymbol{C} \boldsymbol{\sigma}
$$

と書く。

ここで, 式（８）をマトリックス表示するために, 式 (8) の各項を考察する。要素内でモーメントを一定と 仮定しているために, 式 ( 8 ) における $M,{ }_{\beta}{ }^{\alpha \beta}{ }^{\beta} w,_{\alpha}$ の項 は存在しない。また，

$$
\begin{aligned}
\int_{A_{m}} B\left(M^{\alpha \beta}\right) d A & =\frac{1}{2} \int_{A_{m}} \boldsymbol{\sigma}^{T} \boldsymbol{N} \boldsymbol{\sigma} d A \\
& =\frac{A_{m}}{2} \boldsymbol{\sigma}_{n}{ }^{T}\left(\boldsymbol{E}^{-1}\right)^{T} \boldsymbol{N} \boldsymbol{E}^{-1} \boldsymbol{\sigma}_{n} \\
\ldots \ldots \ldots \ldots \ldots \ldots \ldots \ldots \ldots \ldots \ldots \ldots \ldots \ldots & \\
\int_{A_{m}} \bar{p} w d A & =\boldsymbol{w}^{T} \overline{\boldsymbol{p}} \ldots \ldots \ldots \ldots \ldots \ldots \ldots
\end{aligned}
$$

ここに, $\boldsymbol{w}^{T}=\left\{w_{1} w_{2} w_{3}\right\} \quad$ で, $w_{i}(i=1,2,3)$ は要素の 3 つの頂点に設けた節点の変位である（Fig. 3)。ま た, $A_{m}$ は三角形要素 $m$ の面積である。次に, 要素内 


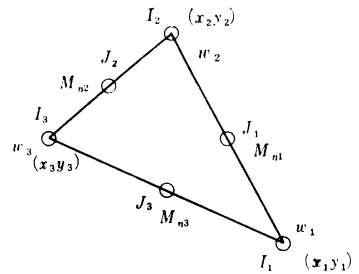

Fig. 3 Nodal Point System and Nodal Parameters で線形分布と仮定した変位の, 三角形要素の 3 つの辺に おける，辺に沿った方向の勾配 w, si は

$$
\begin{aligned}
\left\{\begin{array}{l}
w, s 1 \\
w, s 2 \\
w, s 3
\end{array}\right\} & =\left[\begin{array}{lll}
0 & -s_{1} & c_{1} \\
0 & -s_{2} & c_{2} \\
0 & -s_{3} & c_{3}
\end{array}\right]\left[\begin{array}{ccc}
1 & x_{1} & y_{1} \\
1 & x_{2} & y_{2} \\
1 & x_{3} & y_{3}
\end{array}\right]^{-1}\left\{\begin{array}{l}
w_{1} \\
w_{2} \\
w_{3}
\end{array}\right\} \\
& =\left[\begin{array}{ccc}
-1 / a_{1} & 1 / a_{1} & 0 \\
0 & -1 / a_{2} & 1 / a_{2} \\
1 / a_{3} & 0 & -1 / a_{3}
\end{array}\right]\left\{\begin{array}{l}
w_{1} \\
w_{2} \\
w_{3}
\end{array}\right\} \cdots
\end{aligned}
$$

と与えられるから，

$$
\begin{array}{r}
\oint_{S_{m}} w,{ }_{s} M_{n s} d S=\sum_{i j=1}^{3} \int_{0}^{a_{i} j} \frac{w_{j}-w_{i}}{a_{i j}} M_{n s i j} d S \\
=\boldsymbol{w}^{\boldsymbol{T}} \boldsymbol{F} \boldsymbol{\sigma}_{n s}=\boldsymbol{w}^{\boldsymbol{T}} \boldsymbol{F} \boldsymbol{C \boldsymbol { E } ^ { - 1 }} \boldsymbol{\sigma}_{n} \cdots \\
\boldsymbol{F}=\left[\begin{array}{rrr}
-1 & 0 & 1 \\
1 & -1 & 0 \\
0 & 1 & -1
\end{array}\right] \ldots \ldots \ldots \ldots \ldots \ldots \ldots \ldots \ldots \ldots \ldots
\end{array}
$$

となる。ここに, $\left(x_{i}, y_{i}\right) i=1,2,3$ は三角形要素の 3 つの頂点の座標, $a_{i}$ は要素の辺 $i$ の長さである。また

$$
\begin{aligned}
& \int_{S_{m}} \bar{V}_{n} w d S=\sum_{i j=1}^{3} \int_{0}^{a_{i j}}\left\{\left(1-\frac{s}{a_{i j}}\right) w_{i}\right. \\
& \left.+\frac{s}{a_{i j}} w_{j}\right\} \bar{V}_{n i j} d S \\
& =\boldsymbol{w}^{T} \boldsymbol{L} \overline{\boldsymbol{V}}_{n} \\
& \boldsymbol{L}=\left[\begin{array}{ccc}
a_{1} / 2 & 0 & a_{3} / 2 \\
a_{1} / 2 & a_{2} / 2 & 0 \\
0 & a_{2} / 2 & a_{3} / 2
\end{array}\right]
\end{aligned}
$$

ここに, $\overline{\boldsymbol{V}}_{n}^{T}=\left\{\bar{V}_{n 1} \bar{V}_{n 2} \bar{V}_{n 3}\right\}$ であり

$$
\begin{aligned}
\int_{S_{m}} \bar{w},{ }_{n} M_{n} d S & =\overline{\boldsymbol{w}}_{n}{ }^{T} \boldsymbol{M} \boldsymbol{\sigma}_{n} \cdots \\
\boldsymbol{M} & =\left[\begin{array}{ccc}
a_{1} & 0 & 0 \\
0 & a_{2} & 0 \\
0 & 0 & a_{3}
\end{array}\right]
\end{aligned}
$$

ここに, $\overline{\boldsymbol{w}}_{n}{ }^{T}=\left\{\overline{\boldsymbol{w}},{ }_{n 1} \overline{\boldsymbol{w}},{ }_{n 2} \overline{\boldsymbol{w}},{ }_{n 3}\right\}$ である。

したがって, 式 (8) は要素 $m$ に関して次のように 書くことができる。

$$
\begin{aligned}
-\Pi_{r m}= & \frac{A_{m}}{2} \boldsymbol{\sigma}_{n}^{T}\left(\boldsymbol{E}^{-1}\right)^{T} \boldsymbol{N} \boldsymbol{E}^{-1} \boldsymbol{\sigma}_{n}+\boldsymbol{w}^{T} \overline{\boldsymbol{p}} \\
& +\boldsymbol{w}^{T} \boldsymbol{F} \boldsymbol{C} \boldsymbol{E}^{-1} \boldsymbol{\sigma}_{n}+\boldsymbol{w}^{T} \boldsymbol{L} \overline{\boldsymbol{V}}_{n}+\overline{\boldsymbol{w}}_{n}{ }^{T} \boldsymbol{M} \boldsymbol{\sigma}_{n}
\end{aligned}
$$

式 (18) の停留条件

$$
\begin{aligned}
-\delta \Pi_{r m}= & \delta \boldsymbol{\sigma}_{n}{ }^{T}\left[A_{m}\left(\boldsymbol{E}^{-1}\right)^{T} \boldsymbol{N} \boldsymbol{E}^{-1} \boldsymbol{\sigma}_{n}\right. \\
& \left.+\left(\boldsymbol{E}^{-1}\right)^{T} \boldsymbol{C}^{T} \boldsymbol{F}^{T} \boldsymbol{w}+\boldsymbol{M} \overline{\boldsymbol{w}}_{n}\right]
\end{aligned}
$$

$$
\begin{aligned}
& +\delta \boldsymbol{w}^{T}\left(\boldsymbol{F C E} \boldsymbol{E}^{-1} \boldsymbol{\sigma}_{n}+\boldsymbol{L} \overline{\boldsymbol{V}}_{n}+\overline{\boldsymbol{p}}\right) \\
= & \left\{\delta \boldsymbol{w}^{T} \delta \boldsymbol{\sigma}_{n}{ }^{T}\right\} \\
& \left(\left[\begin{array}{cc}
\boldsymbol{O} & \boldsymbol{F} \boldsymbol{C} \boldsymbol{E}^{-1} \\
\left(\boldsymbol{E}^{-1}\right)^{T} \boldsymbol{C}^{T} \boldsymbol{F}^{T} & A_{m}\left(\boldsymbol{E}^{-1}\right)^{T} \boldsymbol{N} \boldsymbol{E}^{-1}
\end{array}\right]\left\{\begin{array}{l}
\boldsymbol{w} \\
\boldsymbol{\sigma}_{n}
\end{array}\right\}\right. \\
+ & \left.\left\{\begin{array}{c}
\boldsymbol{L} \overline{\boldsymbol{V}}_{n}+\overline{\boldsymbol{p}} \\
\boldsymbol{M} \overline{\boldsymbol{w}}_{n}
\end{array}\right\}\right)=0
\end{aligned}
$$

より, 次の形の有限要素マトリックス

$$
\left[\begin{array}{cc}
\boldsymbol{O} & \boldsymbol{H} \\
\boldsymbol{H}^{T} & \boldsymbol{G}
\end{array}\right]\left\{\begin{array}{c}
\boldsymbol{w} \\
\boldsymbol{\sigma}_{n}
\end{array}\right\}+\left\{\begin{array}{c}
\boldsymbol{L} \overline{\boldsymbol{V}}_{n}+\bar{p} \\
\boldsymbol{M} \overline{\boldsymbol{w}}_{n}
\end{array}\right\}=0
$$

をうることができる。ここに，

$$
\begin{aligned}
& \boldsymbol{H}=\boldsymbol{F} \boldsymbol{C} \boldsymbol{E}^{-1} \\
& \boldsymbol{G}=A_{m}\left(\boldsymbol{E}^{-1}\right)^{T} \boldsymbol{N} \boldsymbol{E}^{-1}
\end{aligned}
$$

である。また, $\boldsymbol{O}$ は 3 行 3 列の零マトリックスである。 式 (20) が Herrmann の与えた平板曲げの有限要素 マトリックスであるが，これと同一の要素が一般の応力 分布仮定や変位分布仮定からも誘導することができるこ とを以下に示す。

\section{4. 応力分布仮定からの誘導}

ここで扱ら方法は, 要素内で応力分布形を仮定し, 要 素周辺で変位分布を仮定することによって, 要素の剛性 マトリックスを誘導しようとするものである。まず, こ の方法の定式過程を概括する。

要素内の応力 $\boldsymbol{\sigma}$ の分布を, 次式のように与える。

$$
\boldsymbol{\sigma}=\boldsymbol{\phi} \boldsymbol{\beta}
$$

ここに, $\boldsymbol{\phi}$ は座標の関数であり, $\boldsymbol{\beta}$ は未知係数のベクト ルである。また, 式 (23) は応力 $\boldsymbol{\sigma}$ が平衡条件を満た すように決められる。要素内のひずみ $\epsilon$ は, 弾性定数の マトリックス $\boldsymbol{N}$ によって,

$$
\boldsymbol{\epsilon}=\boldsymbol{N} \boldsymbol{\sigma}
$$

のように表わされる。要素の境界辺上の変位 $\boldsymbol{u}_{B}$ を, 節 点変位 $\boldsymbol{u}$ の関数として

$$
\boldsymbol{u}_{B}=\boldsymbol{L}_{s} \boldsymbol{u}
$$

と表わす。境界辺上の変位 $\boldsymbol{u}_{B}$ に対応する境界辺上の力 $\boldsymbol{f}_{B}$ は，要素内で仮定した応力分布によって表わすこと ができるから, 応力分布の係数ベクトル $\boldsymbol{\beta}$ によって

$$
\boldsymbol{f}_{B}=\boldsymbol{R} \boldsymbol{\beta}
$$

と表わすことができる。

個々の要素の節点力とそれに対応する節点変位との関 係を求めるという意味において, 個々の要素に関する相 補エネルギー関数を考える。すなわち, 要素 $m$ の相補 エネルギー関数 $\Pi_{c m}$ は

$$
I_{c m}=\frac{1}{2} \int_{A_{m}} \boldsymbol{\sigma}^{T} \boldsymbol{N} \boldsymbol{\sigma} d A-\boldsymbol{f}^{T} \boldsymbol{u}
$$

である。ここに，f は節点変位 $\boldsymbol{u}$ に対応する節点力で ある。いま, 式 (27) における $\boldsymbol{f}^{T} \boldsymbol{u}$ は, 仮想仕事の定 義より 


$$
\boldsymbol{f}^{T} \boldsymbol{u}=\oint \boldsymbol{f}_{B}{ }^{T} \boldsymbol{u}_{B} d S
$$

であり, 式 (28) に式（25）および（26）を代入して

$$
\boldsymbol{f}^{T} \boldsymbol{u}=\boldsymbol{\beta}^{T} \oint \boldsymbol{R}^{T} \boldsymbol{L}_{s} d S \boldsymbol{u}
$$

したがって, 式（27）に式（23）および（29）を代入し $\tau$

$$
\Pi_{c m}=\frac{1}{2} \boldsymbol{\beta}^{T} \int_{A m} \boldsymbol{\phi}^{T} \boldsymbol{N} \boldsymbol{\phi} d A \boldsymbol{\beta}-\boldsymbol{\beta}^{T} \oint \boldsymbol{R}^{T} \boldsymbol{L}_{s} d S \boldsymbol{u}
$$

をらる。式 (30) の停留条件から

$$
\boldsymbol{H}_{c} \beta=\boldsymbol{T}_{c} u
$$

をうる。ここに，

$$
\begin{aligned}
\boldsymbol{H}_{c} & =\int_{A_{m}} \boldsymbol{\phi}^{T} \boldsymbol{N} \boldsymbol{\phi} d A . \\
\boldsymbol{T}_{c} & =\oint \boldsymbol{R}^{T} \boldsymbol{L}_{s} d S \ldots \ldots .
\end{aligned}
$$

である。式 (31) を式 (29) に代入して

$$
\boldsymbol{f}=\boldsymbol{T}_{c}{ }^{T} \boldsymbol{H}_{c}{ }^{-1} \boldsymbol{T}_{c} \boldsymbol{u}
$$

をうる。したがって, 要素の剛性マトリックス $\boldsymbol{k}$ は

$$
\boldsymbol{k}=\boldsymbol{T}_{c}{ }^{T} \boldsymbol{H}_{c}^{-1} \boldsymbol{T}_{c}
$$

\section{と与えられる。}

ここで, 三角形要素の各頂点と各辺の中央に節点を設 け，各頂点に設けた節点においてはたわみ wを，また 各辺の中央に設けた節点においては, その辺の法線方向 のたわみの勾配 $w, n_{n}$ を節点変位として設定し, 三角形 要素内でモーメント $M_{x}, M_{y}, M_{x y}$ が一定であるという 応力分布仮定に基づいて, 平板曲げの有限要素マトリッ クスを定式化する。

三角形要素の各辺上における曲げモーメント $\boldsymbol{\sigma}_{\boldsymbol{n}}$ およ びねじりモーメント $\boldsymbol{\sigma}_{n s}$ は, 式 (10) および式 (11) に 示されたよらに, 要素内のモーメント $\boldsymbol{\sigma}$ の関数として,

$$
\begin{aligned}
& \boldsymbol{\sigma}_{n}=\boldsymbol{E} \boldsymbol{\sigma} \ldots \ldots \ldots \ldots \\
& \boldsymbol{\sigma}_{n s}=\boldsymbol{C} \boldsymbol{\sigma}=\boldsymbol{C E} \boldsymbol{E}^{-1} \boldsymbol{\sigma}_{n}
\end{aligned}
$$

と与えられる。いま, 要素の 各辺の中央に設けた節点にお ける, 曲げモーメント $M_{n}$ に対応する変位 $w,{ }_{n}$ の符号 を, Herrmann の要素と対応 して, $M_{n}$ の正の向きと逆向

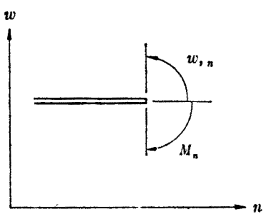

Fig. 4 Sign Convention きに正として設定する (Fig. 4)。また, 要素辺上の変 位 $w,{ }_{n}$ は節点変位によって一義的に決まるように, 辺 上で一定であると仮定すれば， $\sigma_{n}$ が一定であるから， 式 (28) の周辺積分のうち $\boldsymbol{\sigma}_{\boldsymbol{n}}$ に相当する部分は

$$
-\oint \boldsymbol{\sigma}_{n}{ }^{T} \boldsymbol{w}_{n} d S=-\boldsymbol{\sigma}_{n}{ }^{T}\left[\begin{array}{ccc}
a_{1} & 0 & 0 \\
0 & a_{2} & 0 \\
0 & 0 & a_{3}
\end{array}\right] \boldsymbol{w}_{n}=-\boldsymbol{\sigma}_{n}{ }^{T} \boldsymbol{M} \boldsymbol{w}_{n}
$$

となる。式 (38) より節点変位 $\boldsymbol{w}_{n}$ に対応する等価な節 点力が 一 $\boldsymbol{M} \boldsymbol{\sigma}_{\boldsymbol{n}}$ と与えられることがわかる。また, 要素 内でモーメントが一定であるから, 辺上の換算せん断力 は零となり, ねじりモーメントの不連続から生ずる, 三 角形要素の各頂点における集中力 $P_{i}(i=1,2,3)$ が

$$
\left\{\begin{array}{l}
P_{1} \\
P_{2} \\
P_{3}
\end{array}\right\}=\left[\begin{array}{rrr}
1 & 0 & -1 \\
-1 & 1 & 0 \\
0 & -1 & 1
\end{array}\right]\left\{\begin{array}{l}
M_{n s 1} \\
M_{n s 2} \\
M_{n s 3}
\end{array}\right\}
$$

と表わされる。式 (39) は式 (15) と対応する関係式で あり,

$$
\boldsymbol{P}=-\boldsymbol{F} \boldsymbol{\sigma}_{n \boldsymbol{s}}=-\boldsymbol{F C E} \boldsymbol{E}^{-1} \boldsymbol{\sigma}_{\boldsymbol{n}}
$$

と書くことができる。ここに，

$$
\boldsymbol{P}^{T}=\left\{P_{1} P_{2} P_{3}\right\}
$$

である。したがって, 要素の頂点に設けた節点における 節点変位を $w_{i}$ として $\boldsymbol{w}^{T}=\left\{w_{1} w_{2} w_{3}\right\}$ と表わせば, 式 （27）における $\boldsymbol{f}^{T} \boldsymbol{u}$ の項は

$$
\boldsymbol{f}^{T} \boldsymbol{u}=\boldsymbol{P}^{T} \boldsymbol{w}-\boldsymbol{\sigma}_{n}{ }^{T} \boldsymbol{M} \boldsymbol{w}_{n}
$$

となるから, 要素 $m$ の相補エネルギー関数 $\Pi_{c m}$ は

$$
\Pi_{c m}=\frac{1}{2} \int_{A_{m}} \sigma^{T} N \boldsymbol{\sigma} d A-\boldsymbol{P}^{T} \boldsymbol{w}+\boldsymbol{\sigma}_{n}{ }^{T} M w_{n}
$$

と表わされる。

式 (42) に式 (36) および (40) を代入して

$$
\begin{aligned}
\Pi_{c m}= & \frac{A_{m}}{2} \sigma_{n}{ }^{T}\left(\boldsymbol{E}^{-1}\right)^{T} \boldsymbol{N} \boldsymbol{E}^{-1} \boldsymbol{\sigma}_{n} \\
& +\boldsymbol{\sigma}_{n}{ }^{T}\left(\boldsymbol{E}^{-1}\right)^{T} \boldsymbol{C}^{T} \boldsymbol{F}^{T} \boldsymbol{w}+\boldsymbol{\sigma}_{n}{ }^{T} \boldsymbol{M} \boldsymbol{w}_{n}
\end{aligned}
$$

を得る。また, 式 (43) は式（21）および（22）より

$$
\Pi_{c m}=\frac{1}{2} \boldsymbol{\sigma}_{n}^{T} \boldsymbol{G} \boldsymbol{\sigma}_{n}+\boldsymbol{\sigma}_{n}^{T}\left\{\boldsymbol{H}^{T} \boldsymbol{M}\right\} \boldsymbol{u}
$$

と書くことができる。ここに，

$$
\boldsymbol{u}=\left\{\begin{array}{c}
\boldsymbol{w} \\
\boldsymbol{w}_{n}
\end{array}\right\}
$$

である。

したがって, 式 (44) の停留条件より

$$
\boldsymbol{G} \boldsymbol{\sigma}_{n}=-\left\{\boldsymbol{H}^{T} \boldsymbol{M}\right\} \boldsymbol{u}
$$

をうる。一方, 式 (40) を式 (41) に代入すれば

$$
\boldsymbol{f}^{T} \boldsymbol{u}=-\boldsymbol{\sigma}_{n}{ }^{T}\left\{\boldsymbol{H}^{T} \boldsymbol{M}\right\} \boldsymbol{u}
$$

と得られるから, 式 (47) に式 (46) を代入して

$$
\boldsymbol{f}=\left\{\begin{array}{c}
\boldsymbol{H} \\
\boldsymbol{M}
\end{array}\right\} \boldsymbol{G}^{-1}\left\{\boldsymbol{H}^{T} M\right\} \boldsymbol{u}=k \boldsymbol{u}
$$

となり, 要素の剛性マトリックス $k$ が

$$
k=\left[\begin{array}{ll}
H G^{-1} H^{T} & H G^{-1} M \\
M G^{-1} H^{T} & M G^{-1} M
\end{array}\right]
$$

と得られる。

ここで注意しなければならないのは, 誘導に先立って 設定された節点変位 $w, n$ が個々の要素に固有の座標系 に関する変位であって, 要素閒で共通の座標系に関する 変位ではないことである。したがって, 式 (49) に与え られた剛性マトリックスによって, 構造全体系の剛性マ 
トリックスを構成しようとする場合には，新たに節点変 位 $w,_{n}$ の符号に関する考虑が必要である。

いま，要素間で要素の辺上の曲げモーメント $M_{n}$ が 連続するという条件で, 構造全体系の解析を進めること が可能である。すなわち, 剛性マトリックスの誘導過程 に㧊いて考察したように，節点力 $\boldsymbol{f}$ の物理的意義は

$$
\boldsymbol{f}=\left\{\begin{array}{c}
\boldsymbol{P} \\
-\boldsymbol{M} \boldsymbol{\sigma}_{n}
\end{array}\right\}
$$

である。したがって，式（48）に与えられた関係式を具 体的に表わせば

$$
\left\{\begin{array}{c}
\boldsymbol{P} \\
-M \sigma_{n}
\end{array}\right\}=\left[\begin{array}{ll}
\boldsymbol{k}_{11} & \boldsymbol{k}_{12} \\
\boldsymbol{k}_{21} & \boldsymbol{k}_{22}
\end{array}\right]\left\{\begin{array}{c}
\boldsymbol{w} \\
\boldsymbol{w}_{n}
\end{array}\right\}
$$

と書くことができる。いま，式（50）より得られる方程 式

$$
\begin{aligned}
P & =k_{11} w+k_{12} w_{n} \\
-M \sigma_{n} & =k_{21} w+k_{22} w_{n}
\end{aligned}
$$

を解いて, 次の形の関係式に変換する。すなわち，

$$
\left\{\begin{array}{c}
\boldsymbol{P} \\
\boldsymbol{M} w_{n}
\end{array}\right\}=\left[\begin{array}{cc}
k_{11}-k_{12} k_{22}{ }^{-1} k_{21} & -k_{12} k_{22}{ }^{-1} M \\
-M k_{22}{ }^{-1} k_{21} & -M k_{22}{ }^{-1} M
\end{array}\right]\left\{\begin{array}{c}
w \\
\sigma_{n}
\end{array}\right\}
$$

式 (53) の各部分マトリックスに式（49）の剛性マトリ ックスの成分を代入すれば

$$
\left\{\begin{array}{c}
\boldsymbol{P} \\
\boldsymbol{M w _ { n }}
\end{array}\right\}=-\left[\begin{array}{cc}
\boldsymbol{O} & \boldsymbol{H} \\
\boldsymbol{H}^{\mathbf{T}} & \boldsymbol{G}
\end{array}\right]\left\{\begin{array}{l}
\boldsymbol{w} \\
\boldsymbol{\sigma}_{n}
\end{array}\right\}
$$

が得られる。式 (54) 淂られた有限要素マトリックス は, 式 (20) に与えられた有限要素マトリックスとまっ たく同一のものであることは一目瞭然である。

\section{5. 変位分布仮定からの誘導}

ここでは, Fig. 5 に示すように, 三角形要素の各辺 の中央に設けた節点において, 辺の法線方向の勾配 $w_{n_{i}}(i=1,2,3)$ を, 要素の各頂点に設けた節点におい $\tau$, 鉛直変位 $w_{i}(i=1,2,3)$ を節点変位として設定し た平板曲げの有限要素マトリックスを誘導する。

いま, 要素の変位関数を 2 次の多項式で, 次のように 与える。すなわち,

$$
w(x, y)=\left\langle\begin{array}{llllll}
1 & x & y & x^{2} & y^{2} & x y
\end{array}\right\rangle\left\{\begin{array}{c}
q_{1} \\
\vdots \\
q_{6}
\end{array}\right\}
$$

したがって, 要素の曲率 $\boldsymbol{\epsilon}$ は, 式 (55) を微分すること

$$
\boldsymbol{A}=\left[\begin{array}{cccccc}
1 & x_{1} & y_{1} & x_{1}{ }^{2} & y_{1}{ }^{2} & x_{1} y_{1} \\
1 & x_{2} & y_{2} & x_{2}{ }^{2} & y_{2}{ }^{2} & x_{2} y_{2} \\
1 & x_{3} & y_{3} & x_{3}{ }^{2} & y_{3}{ }^{2} & x_{3} y_{3} \\
0 & c_{1} & s_{1} & c_{1}\left(x_{1}+x_{2}\right) & s_{1}\left(y_{1}+y_{2}\right) & \frac{1}{2}\left\{c_{1}\left(y_{1}+y_{2}\right)+s_{1}\left(x_{1}+x_{2}\right)\right\} \\
0 & c_{2} & s_{2} & c_{2}\left(x_{2}+x_{3}\right) & s_{2}\left(y_{2}+y_{3}\right) & \frac{1}{2}\left\{c_{2}\left(y_{2}+y_{3}\right)+s_{2}\left(x_{2}+x_{3}\right)\right\} \\
0 & c_{3} & s_{3} & c_{3}\left(x_{3}+x_{1}\right) & s_{3}\left(y_{3}+y_{1}\right) & \frac{1}{2}\left\{c_{3}\left(y_{3}+y_{1}\right)+s_{3}\left(x_{3}+x_{1}\right)\right\}
\end{array}\right] \cdots
$$

であるから，式 (55) および (59) に各節点の座標を代 入して, 式 (58) のマトリックス $\boldsymbol{A}$ は次のように表わ される。

$$
\begin{aligned}
& \boldsymbol{\epsilon}=\left\{\begin{array}{c}
w,,_{x x} \\
w,_{y y} \\
2 w,_{x y}
\end{array}\right\}=\left[\begin{array}{llllll}
0 & 0 & 0 & 2 & 0 & 0 \\
0 & 0 & 0 & 0 & 2 & 0 \\
0 & 0 & 0 & 0 & 0 & 2
\end{array}\right] \boldsymbol{q} \\
& =2\left\{\begin{array}{ll}
\boldsymbol{O} & \boldsymbol{I}
\end{array}\right\} \boldsymbol{q}
\end{aligned}
$$

のように得られる。ここに, $\boldsymbol{O}$ は 3 行 3 列の零マトリッ クスであり, I は 3 行 3 列の単位マトリックスである。 また, 要素内のモーメント $\boldsymbol{\sigma}$ と曲率 $\boldsymbol{\epsilon}$ の関係は, 次の ように与えられる。

$$
\boldsymbol{\sigma}=\left\{\begin{array}{l}
M_{x} \\
M_{y} \\
M_{x y}
\end{array}\right\}=-D\left[\begin{array}{ccc}
1 & \nu & 0 \\
\nu & 1 & 0 \\
0 & 0 & \frac{1-\nu}{2}
\end{array}\right] \boldsymbol{\epsilon}
$$

ここに, $D$ は板の曲げ剛性で $D=E h^{3} / 12\left(1-\nu^{2}\right)$ であ る。

$$
\begin{aligned}
& \text { 式 (57) を } \\
& \boldsymbol{\sigma}=-\boldsymbol{D} \boldsymbol{\epsilon}
\end{aligned}
$$

のように書く。

ここで, 式 (55) に与えた変位関数の係数ベクトル $\boldsymbol{q}$ を, 節点変位 $\boldsymbol{u}$ の関数として求めるために, まず, $\boldsymbol{u}$ を $\boldsymbol{q}$ の関数として次のように表わす。

$$
\boldsymbol{u}=\boldsymbol{A q}
$$

いま,

$$
\begin{aligned}
& w,_{n i}=c_{i} w,{ }_{x}+s_{i} w,{ }_{y} \\
& \left.=\begin{array}{lllllll}
0 & c_{i} & s_{i} & 2 c_{i} x & 2 & s_{i} y & c_{i} y+s_{i} x
\end{array}\right\rangle \boldsymbol{q}
\end{aligned}
$$


したがって, $\boldsymbol{q}$ が $\boldsymbol{u}$ の関数として

$$
\boldsymbol{q}=\boldsymbol{B} \boldsymbol{u}
$$

のように得られる。ここに

$$
\boldsymbol{B}=\boldsymbol{A}^{-1}
$$

である。

いま, 要素 $m$ に関するポテンシャルエネルギー関数 $\Pi_{p m}$ は

$$
\Pi_{p m}=\frac{1}{2} \int_{A_{m}} \boldsymbol{\epsilon}^{T} \boldsymbol{D} \boldsymbol{\epsilon} d A-\boldsymbol{u}^{T} \boldsymbol{f}
$$

と表わされ，式（63）に式（56）および式（61）を代入 して

$$
\Pi_{p m}=\frac{4}{2} \boldsymbol{u}^{T} \boldsymbol{B}^{T} \int_{A_{m}}\left\{\begin{array}{l}
\boldsymbol{O} \\
\boldsymbol{I}
\end{array}\right\} \boldsymbol{D}\left\{\begin{array}{ll}
\boldsymbol{O} & \boldsymbol{I}
\end{array} d A \boldsymbol{B} \boldsymbol{u}-\boldsymbol{u}^{T} \boldsymbol{f}\right.
$$

をらる。式 (64) の停留条件より

$$
\boldsymbol{f}=4 A_{m} \boldsymbol{B}^{T}\left[\begin{array}{ll}
\boldsymbol{O} & \boldsymbol{O} \\
\boldsymbol{O} & \boldsymbol{D}
\end{array}\right] \boldsymbol{B u}
$$

と与えられる。いま，マトリックス $\boldsymbol{B}$ を 3 行 3 列の 4 つの部分マトリックスに分割して, 次のように表わす。 すなわち,

$$
\boldsymbol{B}=\left[\begin{array}{ll}
\boldsymbol{B}_{11} & \boldsymbol{B}_{12} \\
\boldsymbol{B}_{21} & \boldsymbol{B}_{22}
\end{array}\right]
$$

とおけば, 式 (65) より要素の剛性ママトリックス $k$ は

$$
\boldsymbol{k}=\left[\begin{array}{ll}
\boldsymbol{k}_{11} & \boldsymbol{k}_{12} \\
\boldsymbol{k}_{21} & \boldsymbol{k}_{22}
\end{array}\right]=4 A_{m}\left[\begin{array}{ll}
\boldsymbol{B}_{21}{ }^{T} \boldsymbol{D} \boldsymbol{B}_{21} & \boldsymbol{B}_{21}{ }^{T} \boldsymbol{D} \boldsymbol{B}_{22} \\
\boldsymbol{B}_{22}{ }^{T} \boldsymbol{D} \boldsymbol{B}_{21} & \boldsymbol{B}_{22}{ }^{T} \boldsymbol{D} \boldsymbol{B}_{22}
\end{array}\right]
$$

と得られる。ここで, 式 (67) に得られた岡性マトリッ クスが，式(20) に与えられた Herrmannのモデルと等 価であることを示す。

ここで扱っている要素に関しては, 要素の変位形を 2 次式で仮定した時点において, その反面に, 要素周辺上 の曲げモーメント $M_{n}$ が一定であることおよび $M_{n}$ に 対応する, 要素周辺の法線方向の勾配 $w,{ }_{n}$ が一次分布 していることが了解される。また, 式 (20) における節 点力 $\sigma_{n}$ と符号を対応させれば, 式 (65) の節点力 $f$ の 内容は

$$
\boldsymbol{f}=\left\{\begin{array}{c}
\boldsymbol{P} \\
-\boldsymbol{M} \boldsymbol{\sigma}_{n}
\end{array}\right\}
$$

であることが明らかである（Fig. 4)。したがって，式 （65）を具体的に表わせば

$$
\left\{\begin{array}{c}
\boldsymbol{P} \\
-\boldsymbol{M} \boldsymbol{\sigma}_{n}
\end{array}\right\}=\left[\begin{array}{ll}
\boldsymbol{k}_{11} & \boldsymbol{k}_{12} \\
\boldsymbol{k}_{21} & \boldsymbol{k}_{22}
\end{array}\right]\left\{\begin{array}{c}
\boldsymbol{w} \\
\boldsymbol{w}_{n}
\end{array}\right\}
$$

である。式 (69) を分解して, 式 (20) と対応するよう に書き直せば

$$
\left\{\begin{array}{c}
\boldsymbol{P} \\
\boldsymbol{M} \boldsymbol{w}_{n}
\end{array}\right\}=-\left[\begin{array}{cc}
-\boldsymbol{k}_{11}+\boldsymbol{k}_{12} \boldsymbol{k}_{22}^{-1} \boldsymbol{k}_{21} & \boldsymbol{k}_{12} \boldsymbol{k}_{22}^{-1} \boldsymbol{M} \\
\boldsymbol{M} \boldsymbol{k}_{22}{ }^{-1} \boldsymbol{k}_{21} & \boldsymbol{M} \boldsymbol{k}_{22}{ }^{-1} \boldsymbol{M}
\end{array}\right]\left\{\begin{array}{l}
\boldsymbol{w} \\
\boldsymbol{\sigma}_{n}
\end{array}\right\}
$$

となる。いま, 式 (67) に与えられた各部分マトリック ス $\boldsymbol{k}_{i j}$ を式 (70) に代入して整理すれば, 式 (70) は

$$
\begin{aligned}
& \left\{\begin{array}{c}
\boldsymbol{P} \\
M w_{n}
\end{array}\right\} \\
& =-\left[\begin{array}{cc}
\boldsymbol{O} & \boldsymbol{B}_{21}{ }^{T}\left(\boldsymbol{B}_{22}{ }^{-1}\right)^{T} \boldsymbol{M} \\
\boldsymbol{M} \boldsymbol{B}_{22}{ }^{-1} \boldsymbol{B}_{21} & \frac{1}{4 A_{m}} \boldsymbol{M B}_{22}{ }^{-1} \boldsymbol{D}^{-1}\left(\boldsymbol{B}_{22}{ }^{-1}\right)^{T} \boldsymbol{M}
\end{array}\right] \\
& \times\left\{\begin{array}{l}
\boldsymbol{w} \\
\boldsymbol{\sigma}_{n}
\end{array}\right\}
\end{aligned}
$$

となる。また, マトリックス $\boldsymbol{B}$ は, 式 (62) に示され るよらに, 式 (60) に与えられたマトリックス $\boldsymbol{A}$ の逆 マトリックスであるから, マトリックス $\boldsymbol{A}$ を 3 行 3 列 の 4 つの部分マトリックスに分割して

$$
\boldsymbol{A}=\left[\begin{array}{ll}
A_{11} & A_{12} \\
A_{21} & A_{22}
\end{array}\right]
$$

とすれば

$$
\begin{aligned}
& B_{21}=\left[A_{21} A_{11}^{-1} A_{12}-A_{22}\right]^{-1} A_{21} A_{11}^{-1} \\
& B_{22}=-\left[A_{21} A_{11}{ }^{-1} A_{12}-A_{22}\right]^{-1}
\end{aligned}
$$

である。

いま, 式 (71) のマトリックスの内容が, 式 (20)の マトリックスの内容と同一であることを示すことは, 式 (20) の部分マトリックス $\boldsymbol{H}$ および $\boldsymbol{G}$ が，それぞれ式 (21) 抽よび (22) に与えられるように

$$
\begin{aligned}
& \boldsymbol{H}=\boldsymbol{F} \boldsymbol{C} \boldsymbol{E}^{-1} \\
& \boldsymbol{G}=A_{m}\left(\boldsymbol{E}^{-1}\right)^{T} \boldsymbol{N} \boldsymbol{E}^{-1}
\end{aligned}
$$

であることから，式（71）の内容と対応して

$$
\boldsymbol{F C} \boldsymbol{E}^{-1}=\boldsymbol{B}_{21}^{T}\left(\boldsymbol{B}_{22}^{-1}\right)^{T} \boldsymbol{M}
$$

および

$$
A_{m}\left(\boldsymbol{E}^{-1}\right)^{T} \boldsymbol{N} \boldsymbol{E}^{-1}=\frac{1}{4 A_{m}} \boldsymbol{M B}_{22}^{-1} \boldsymbol{D}^{-1}\left(\boldsymbol{B}_{22}{ }^{-1}\right)^{T} \boldsymbol{M}
$$

を示すことになる。また，上の 2 つの式が成立すること を示すことは，

$$
\boldsymbol{N}=\boldsymbol{D}^{-1}
$$

であることを考虑し，式 (77) および（78）に式 (73) および (74) を代入して,

$$
\boldsymbol{F C E} E^{-1}=-\left(\boldsymbol{A}_{11}^{-1}\right)^{T} \boldsymbol{A}_{21}{ }^{T} M
$$

および

$$
2 A_{m} \boldsymbol{E}^{-1}=\left[\boldsymbol{A}_{22}{ }^{T}-\boldsymbol{A}_{12}{ }^{T}\left(\boldsymbol{A}_{11}{ }^{-1}\right)^{T} \boldsymbol{A}_{21}{ }^{T}\right] \boldsymbol{M} \cdots \text { (81) }
$$

を示すことと等価である。

いま, 式 (14)より

$$
\boldsymbol{F}=\left[\begin{array}{rrr}
-1 & 0 & 1 \\
1 & -1 & 0 \\
0 & 1 & -1
\end{array}\right]=\left(\boldsymbol{A}_{11}{ }^{-1}\right)^{T}\left[\begin{array}{rrr}
0 & 0 & 0 \\
-s_{1} & -s_{2} & -s_{3} \\
c_{1} & c_{2} & c_{3}
\end{array}\right] \boldsymbol{M}
$$

が成立つことがわかる。式（82）を式（80）に代入すれ ば明らかなように, 式（80）が成立つことを示すことは

$$
\left[\begin{array}{rrr}
0 & 0 & 0 \\
-s_{1} & -s_{2} & -s_{3} \\
c_{1} & c_{2} & c_{3}
\end{array}\right]\left[\begin{array}{ccc}
a_{1} & 0 & 0 \\
0 & a_{2} & 0 \\
0 & 0 & a_{3}
\end{array}\right]
$$




$$
\begin{aligned}
\times & {\left[\begin{array}{ccc}
-s_{1} c_{1} & s_{1} c_{1} & c_{1}{ }^{2}-s_{1}{ }^{2} \\
-s_{2} c_{2} & s_{2} c_{2} & c_{2}{ }^{2}-s_{2}{ }^{2} \\
-s_{3} c_{3} & s_{3} c_{3} & c_{3}{ }^{2}-s_{3}{ }^{2}
\end{array}\right] } \\
= & -\left[\begin{array}{ccc}
0 & 0 & 0 \\
c_{1} & c_{2} & c_{3} \\
s_{1} & s_{2} & s_{3}
\end{array}\right]\left[\begin{array}{ccc}
a_{1} & 0 & 0 \\
0 & a_{2} & 0 \\
0 & 0 & a_{3}
\end{array}\right] \\
& \times\left[\begin{array}{llll}
c_{1}{ }^{2} & s_{1}{ }^{2} & 2 & s_{1} c_{1} \\
c_{2}{ }^{2} & s_{2}{ }^{2} & 2 & s_{2} c_{2} \\
c_{3}{ }^{2} & s_{3}{ }^{2} & 2 & s_{3} c_{3}
\end{array}\right] \ldots \ldots \ldots . . .
\end{aligned}
$$

を示すことになり，式（83）が成立つことは，具体的な 計算によって，ただちに示すことができる。

いま, 式 (80) が成立つことが示されたので, 式 (80) を式 (81) に代入して, 式 (81) は

$$
\boldsymbol{A}_{22}{ }^{T} \boldsymbol{M E}+\boldsymbol{A}_{12}{ }^{\boldsymbol{T}} \boldsymbol{F} \boldsymbol{C}=2 A_{m} \boldsymbol{I} \cdot
$$

と変換することができる。式 (84) が成立つことは, 具 体的に計算を進めることによって示すことができる。

したがって, 式 (71) のマトリックスの内容は, 式 (20) のマトリックスの内容とまったく同じものである ことがわかる。

\section{6. 有限要素マトリックスの定式過程に関する 二, 三の考察}

以上に, 3 つの異なった基本仮定から问一の有限要素 が誘導されるという事実を示したのであるが，ここでは このような事実に基づいて有限要素マトリックスの定式 過程における三，三の問題点について考察してみたい。

節点変位 $\boldsymbol{u}$ とこれに対応する与えられた量としての 節点力 $\boldsymbol{f}$ に関して, 要素 $m$ のポテンシャルエネルギー 関数 $\Pi_{p m}$ は

$$
\Pi_{p m}=\frac{1}{2} \boldsymbol{u}^{T} k \boldsymbol{u}-\boldsymbol{u}^{T} \boldsymbol{f}
$$

と与えられる。ここに $\boldsymbol{k}$ は要秦の剛性マトリックスで ある。

また, 要素の変位形 $w(x, y)$ は節点変位 $u_{i}$ の補間 関数, すなわち節点変位ベクトル $\boldsymbol{u}$ の成分のうち, $u_{i}$ に対応するその関数またはその関数の微分形が, $u_{i}$ の 評価される節点において単位の值をとり, $u_{i}$ 以外の成 分に対応するその関数またはその関数の微分形の值は, それぞれの成分が評価される節点においてすべて零とな るような, 要素内でその值およびその微分の值が連続な 関数 $\phi_{i}(x, y)$ の線形結合として

$$
w(x, y)=\Sigma u_{i} \phi_{i}(x, y)
$$

と表わされる。

もし, 要素の変位形が要素間で連続するように与えら れるならば, 構造全体系としての仮想仕事の定義より， 式 (85) のポテンシャルエネルギー $\boldsymbol{u}^{T} \boldsymbol{f}$ は

$$
\boldsymbol{u}^{T} \boldsymbol{f}=\Sigma u_{i} f_{i}=\int_{A_{m}} p w d A
$$

である。ここに，pは実際に作用する外力である。した がって, 式 (87) に式 (86) を代入して, 節点力 $f_{i}$ は

$$
f_{i}=\int_{A_{m}} p \phi_{i} d A
$$

と得られ, 節点変位の補間関数 $\phi_{i}$ が作用荷重 $p$ の重み 関数として表われることがわかる。

いま，5. で扱った要素においては，要素の各頂点で 鉛直変位 $w_{i}$, 各辺の中点で辺の法線方向の勾配 $w,{ }_{n i}$ を 考えているにすぎない。したがって，2 次の多項式で与 えた変位形に対して, 要素間の変位の連続性は保証され ない。しかも, 節点変位 $w,{ }_{n i}$ は個々の要素に個有の座 標系に関する変位であって, 要素間での共通の座標系に 基づくものではない。

それゆえに, 式 (63) の停留条件から式 (67) に求め られた剛性マトリックスは, 個々の要素の節点変位とそ れに対応する節点力との関係を与えるにすぎない。した がって, 式（63） は個々の要素に関して閉じた形でのポ テンシャルエネルギー関数であって, $\boldsymbol{u}^{T} \boldsymbol{f}$ の項は要素内 で閉じた形での仮想仕事の定義より

$$
\boldsymbol{u}^{T} \boldsymbol{f}=\Sigma u_{i} f_{i}=\int_{A_{m}} p w d A+\oint \boldsymbol{u}_{B}^{T} \boldsymbol{f}_{B} d S
$$

である。ここに， $\boldsymbol{f}_{B}$ は要素に作用する要素周辺の力で， 構造全体系においては内力となるものであり， $\boldsymbol{u}_{B}$ は要 素周辺の $\boldsymbol{f}_{B}$ に対応する変位である。

いま, 要素周辺の変位 $\boldsymbol{u}_{B}$ は, 式 (86) に与えられた 変位関数または変位関数の $\boldsymbol{u}_{B}$ の成分に対応する微分形 の, 要素周辺における值として, 要素周辺に沿った座標 系 $s$ の関数として表わすことができる。変位関数が節 点変位 $\boldsymbol{u}$ の関数として与えられるから, 要素周辺の変 位 $\boldsymbol{u}_{B}$ も，やはり節点変位 $\boldsymbol{u}$ の関数として与えられ, これを

$$
u_{B j}=\sum_{i} u_{i} \phi_{i B j}(s)
$$

と書けば，式 (89) は

$$
\begin{aligned}
\boldsymbol{u}^{T} \boldsymbol{f} & =\Sigma u_{i} f_{i} \\
& =\Sigma u_{i} \int_{A_{m}} p \phi_{i} d A+\sum_{j} \sum_{i} u_{i} \oint \phi_{i B j} f_{B j} d S
\end{aligned}
$$

となり，節点力 $f_{i}$ の意義は

$$
f_{i}=\int_{A_{m}} p \phi_{i} d A+\sum_{j} \oint \phi_{i B j} f_{B j} d S
$$

として示される。

一般にとられているように, 変位分布仮定に基づいて 仮想仕事の原理から剛性マトリックスを誘導する場合に は, 要素内に仮定した変位形が要素間で連続な変位を与. えるか否かによらず，その節点力の物理的意義は式(92) 
の形で示されるものであることは，その定式過程を考え れば明らかである。

いま，得られた剛性マトリックスを重社合わせること によって, 構造全体系としての剛性マトリックスを構成 することを考えるならば，これは式（92）の境界辺上の 力の項, すなわち構造全体系としての要素辺上の内力の 項,

$$
\oint \phi_{i B j} f_{B j} d S
$$

が隣接する要素間で相殺されるという意味での要素間の 平衡条件が満たされることによって可能になる。

同様のことが式 (54) に得られた要素マトリックスか ら構造全体系のマトリックスを構成する際にもいうこと ができる。すなわち, 節点変位 $\boldsymbol{w} か ゙$ 連続であり, 要素辺 上の節点で代表される曲げモーメント $\sigma_{n}$ が要素間で連 続するという条件で, 式 (54) に得られた有限要素マト リックスを単純に重㸚わせることによって, 構造全体 系を支配するマトリックスを構成することができる。そ の際,重社合わせた結果として, 式 (54) の左辺の $\boldsymbol{M} \boldsymbol{w}_{\boldsymbol{n}}$ の項の和が構造全体系のマトリックスの左辺に残ること になる。しかし，この $\boldsymbol{M} \boldsymbol{w}_{n}$ の項は平均值的意味に㧍け る要素辺上の辺の法線方向のたわみの勾配を代表する値 であり, 要素間でのたわみの勾配の連続性と $\boldsymbol{w}_{n}$ の符号 の規約を考えれば明らかなように，構造の内部において は，その辺を共有する要素間で相殺される。したがっ て, 最終的には構造全体系の実際の境界における $\boldsymbol{M} \boldsymbol{w}_{n}$ の値だけが残ることになり，これは境界条件として考虑 されるところとなる。

このように，辺上における平均値的意味での平衡条件 または適合条件が満たされ，節点での変位または力の連 続性が満たされるかぎりにおいては, 解が正しい解に収 束するか否かは, 要素内に仮定した変位形または応力分 布形が要素間で連続であるかどうかの問題であるよりは むしろ, 要素内に仮定した変位形または応力分布形が, 比較すべき理論上の支配方程式で与えられる変位形また は応力分布形を矛盾なく表現することができるかどうか によるものであるといらことができる。

すなわち, 与えられた量としての境界辺上の力 $f_{B j}$ は，仮想仕事の方程式から対象の平衡方程式および境界 条件式が誘導される過程を考えれば明らかなように, 要 素の変位形が仮定された時点において，仮定された変位 形の関数として,したがって節点変位の関数として定義 される量である。さきの例題に関して具体的にいえば, 要素の変位形を 2 次式と仮定した時点において，せん断 カが零,曲げおよびねじりモーメントが一定であり，した がって要素周辺上での曲げモーメント $M_{n}$ が一定である ことが反面において了解され，さらに変位形が 2 次式分
布であるから， $M_{n}$ に対応する要素周辺上の法線方向の 勾配は辺上で一次分布である。したがって, 式 (63) に 基づいて式 (67) に誘導された剛性マトリックスが, 応 力分布仮定に基づいて式（49）に与えられた剛性マトリ ックスとまったく同等のものになることは必然である。

いま, 要素の変位形を 3 次の多項式で仮定した場合を 考えてみよう。この場合には，反面において曲げおよび ねじりモーメントが線形分布であることを仮定したこと になる。すなわち, 変位形の関数として与えられ，要素 辺上において一次分布するこれらの力量は，その辺をは さむ両端の節点におけるこれらの力量の值によって一義 的に決まる。したがって，3次の多項式で仮定した変位 形から得られる平板曲げ要素において, 要素間で曲げお よびねじりモーメントの連続性を保証するように定式化 することが可能であり，この場合にはこれらの力量の微 分の不連続量によって表現される平衡関係に基づいて構 造全体系の解析が進められることになる。

このように, 要素周辺上の力 $f_{B j}$ は個々の要素内に 仮定した変位関数に対応して, 節点変位の関数として定 義されることを考えれば，たとえ要素間で変位の連続性 が保証されても, 要素周辺のポテンシャルエネルギー

$$
\oint \phi_{i B j} f_{B j} d S
$$

が要素間で不連続になることは免れられない。すなわ ち, 有限要素法の特性として明記しなければならないの は, 要素内の変位形を有限の自由度のものと仮定するか ぎりに扔いては，仮定した変位形では対応できない高次 の変位形を必要とする作用荷重条件に対しては, 要素分 割を細かくして対象全体の自由度がいかに高められて も，要素内の変位形自体が真の分布型となることができ ず，あくまでも要素周辺における要素間の高次の変位の 不連続量によって表わされる等価な平衡関係が真の分布 型を評価しうるように近づくことによって収束が保証さ れるといらことである。

\section{7. 結論}

以上に, Reissner の変分原理に基づいて, Herrmann によって誘導された平板曲げの有限要素マトリックスと まったく同一の要素が，一般の応力分布仮定や変位分布 仮定からも誘導することができるといら事実を示し，有 限要素マトリックスの定式過程に関する考察を行なっ た。それぞれの誘導過程の対応において問題となるの は, 要素内の変位分布や応力分布の仮定とそれに対応す る要素周辺のエネルギーを代表する節点力または節点変 位の意義であって, その内容によって, 要素マトリック スの内容も当然変わってくる。 
ここで扱ったように，変位分布を 2 次の多項式で仮定 した場合には, 反面に要素内のモーメント分布が一定で あることが了解され，したがって仮定した系における要 素周辺の力の分布およびそれに対応する変位の分布に対 して節点力の意義が明確にまた単純な形に表現され，そ れぞれの要素マトリックスの内容を相対的にまた具体的 に検討することが可能となった。

異なった基本仮定から同一の結果が得られるといら事 実そのものはむしろ当然の結果であって, ここで問題と したいのは, 定式過程におけるこのような事実に基づい た種々の考察であり, 有限要素マトリックスの特性を明 確にとらえることにより, 有限要素解析の新たな可能性 を考えることができるといらことである。

\section{参考文献}

1) Herrmann, L.R. : Finite Element Bending Analysis for Plates; J. of Engg. Mech., Div. ASCE, 93, EM 5, pp. 13-26 (1967).

2) Herrmann, L.R. : A Bending Analysis for Plates; Proc. Conf. on Matrix Methods in Structural Mechanics, AFFDL-TR-66-80, pp. 577-604 (1965).

3) Melosh, R.J. : Basis for Derivation of Matrices for the Direct Stiffness Method; AIAA Jnl., 1, 7, pp. 1631-1637 (1963).

4) Clough, R.W. and J.L. Tocher : Finite Element Stiffness Matrices for Analysis of Plate Bending; Proc. Conf. on Matrix Methods in Structural Mechanics, AFFDL-TR-66-80, pp. 515-546 (1965).

5) Irons, B.M. and K.J. Draper : Inadequacy of Nodal Connections in a Stiffness Solution for Plate Bending; AIAA Jnl. 3, 5, p. 961 (1965)

6) Irons, B.M. : A Conforming Quatric Triangular Element for Plate Bending; Int. J. for Numerical Meth. in Eng., 1, 1, pp. 29-45 (1969).

7) Bell, K. : A Refined Triangular Plate Bending Finite Element; Int. J. for Numerical Meth. in Eng., 1, 1, pp. 101-122 (1969).

8) Bazeley, G.P., Y.K. Cheung, B.M. Irons and O.C. Zienkiewicz : Triangular Elements in Plate BendingConforming and Non-conforming Solutions; Proc. Conf. on Matrix Methods in Structural Mechanics AFFDL-TR-66-80, pp. 547-576 (1965).

9) Bogner, F.K., R.L. Fox and L.A. Schmit, Jr.: The Generation of Inter-element Compatible Stiffness and Mass Matrices by the Une of Interpolation Formulae; Proc. Conf. on Matrix Methods in Structural Mechanics, AFFDL-TR-66-80, pp. 397-444 (1965).

10) Zienkiewicz, O.C., B.M. Irons, J. Ergatoudis, S. Ahmad and F.C. Scott : Iso-Prametric and Associated Element Families for Two- and Three- Dimensional Analysis; in Finite Element Methods in Stress Analysis, (Ed. I. Holand and K. Bell), Chap. 13, TAPIR Trondheim 1969.

11) Argyris, J.H. and S. Kelsey : Energy Theorems and Structural Analysis; Butterworths Scientific Publications 1960.

12) Fraeijs de Veubeke, B. : Displacement and Equilibrium Models in the Finite Element Method; in Stress Analysis, (Ed. O.C. Zienkiewicz and G.S. Holister), Chap. 9, Wiley, London, 1965.
13) Fraeijs de Veubeke, B. and G. Sander : An Equilibrium Model for Plate Bending; Int. Jnl. Solids \& Structs (G.B.), 4, pp. 447-468 (1968).

14) Sander, G. and B. Fraeijs de Veubeke : Upper and Lower Bounds to Structural Deformations by Dual Analysis in Finite Elements; AFFDL-TR-66-199 (1967).

15) Anderheggen, E. : Finite Element Plate Bending Equilibrium Analysis; J. of Engg. Mech. Div. ASCE, 95, EM 4, pp. 841-857 (1969).

16) Morley, L.S.D. : The Triangular Equilibrium Element in the Solution of Plate Bending Problems; Aeronaut. Q., 19, pp. 149-169 (1968).

17) Fraeijs de Veubeke, B. : Bending and Stretching of Plates-Special Models for Upper and Lower Bounds; Proc. Conf. on Matrix Methods in Structural Mechanics, AFFDL-TR-66-80, pp. 863-886 (1965).

18) Fraeijs de Veubeke, B. and O.C. Lienkiewicz: Strain-Energy Bounds in Finite-Element Analysis by Slab Analogy; Jnl. Strain Analysis, 2, 4, pp. 265271 (1967).

19) Pian, T.H.H. : Derivation of Element Stiffness Matrices by Assumed Stress Distributions; AIAA Jnl., 2, pp. 1333-1336 (1964).

20) Pian, T.H.H. : Element Stiffness Matrices for Boundary Compatibility and for Prescribed Boundary Stresses; Proc. Conf. on Matrix Methods in Structural Mechanics, AFFDL-TR-66-80, pp. 457-477 (1965).

21) Severn, R.T. and P.R. Taylor: The Finite Element Method for Flexure of Slabs when Stress Distributions are Assumed; Proc. Instn Civ. Engrs. 34, pp. 153-170 (1966).

22) Allwood, R.J. and G.M.M. Cornes : A Polygonal Finite Element for Plate Bending Problems Using the Assumed Stress Approach; Int. J. for Numerical Meth. in Eng., 1, pp. 135-149 (1969).

23) Yamamoto, Y. : A Formulation of Matrix Displacement Method; Dept. of Aeronautics and Astronautics, M.I.T. 1966.

24) Pian, T.H.H. and P. Tong : Basis of Finite Element Methods for Solid Continua; Int. J. for Numerical Meth. in Eng., 1, 1, pp. 3-28 (1969).

25) Pian, T.H.H. : Formulations of Finite Element Methods for Solid Continua; Recent Advances in Matrix Methods of Structural Analysis and Design (the Proc. of U.S.-Japan Seminar, Tokyo, 1969), University of Alabama Press 1970.

26) Jones, R.E. : A Generalization of the Direct-Stiffness Method of Structural Analysis; AIAA Journal, 2, 5, pp. 821-826 (1964).

27) Washizu, K. : Variational Methods in Elasticity and Plasticity; Pergamon Press, Oxford, 1968.

28) Gallagher, R.H. : Analysis of Plate and Shell Structures; Proc. of the Symposium on Application of Finite Element Methods in Civil Engineering, School of Engineering Vanderbilt University, ASCE, pp. 155-205 (1969).

29) 吉田 裕: 有限要素法による平板曲げの解析, 生産研究, 22, 1, pp. $28 \sim 33$ (1970).

(1971.1.18 - 受付) 